\title{
Discontinuing life support in comatose patients: an example from Canadian case law
}

$\mathrm{T}$ he type and extent of medical intervention that is appropriate for patients in a persistent vegetative state is a matter of painful moral and legal debate, as the Terri Schiavo case in the United States has recently shown. Every day, in intensive care units, families are faced with difficult decisions with regard to life-sustaining interventions that are therapeutically futile. Such situations are especially difficult when the patient has given no advance directive to guide family members and physicians. Many physicians are aware of the Sawatzky case, in which a woman challenged a physician's "do not resuscitate" order in her husband's chart. ${ }^{1}$ Less well known is a case brought to the Surrogate Court of Alberta in 1999, in which the court approved the discontinu-

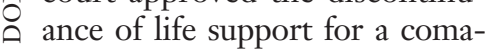

tose, dependent adult with no advance directive. ${ }^{2}$

Robert Kenneth Durksen, a 47-year-old RCMP officer, suffered severe brain injury in a plane crash in June 1999. He was comatose after the injury and required intravenous hydration and nutrition to remain alive. Three months later he remained comatose. At his family's request, a public guardian was appointed as his substitute decision-maker under the terms of the Dependent Adults Act. The appointment of a public guardian was unusual given the existence of family members, but those closest to Const. Durksen preferred that a public guardian be the legal decisionmaker rather than one of them. The governing principle of the Dependent Adults Act is to serve the best interests of the individual concerned, taking

Practical implications of the Alberta court decision in the Durksen case

Ethical points

- Sanctity of life is not an absolute value in the determination of appropriate health care for an incompetent patient

- Maintenance in a persistent vegetative state is not a benefit to the patient

- Appropriateness in health care depends on the facts of a given case

- The best interest of a patient may be met by discontinuance of all interventions except for palliative measures designed to allow a patient to die peacefully, with the greatest dignity and the least pain, suffering and distress

- Artificial hydration and enteral feeding were not distinguished from artificial respiration and seemingly do not have different legal significance from artificial respiration for discontinuance

\section{Procedural points}

- There is a limitation in the powers of a court-appointed guardian. Where there is no advance directive, the guardian as a proxy decision-maker cannot consent to discontinuance nor refuse commencement of life-sustaining interventions without court approval

- The court has inherent power to review, advise and direct in such matters

- Application to court for approval of a palliative care plan involving discontinuance of life support should be built upon prior medicolegal and ethical consultations

into account his or her known views, values and wishes. Specifically, the public guardian had to determine whether continued intravenous hydration and nutrition were in the patient's best interest.

No advance directive had been made by the patient. The public guardian consulted with the family, health care team members and the local clinical ethics committee. After some initial lack of consensus, the family and the patient's common-law partner became united in the belief that he would want his life support to be discontinued. However, given that the Dependent Adults Act is silent on the question of discontinuing life support, the public guardian was reluctant to authorize the discontinuance and applied to the court for advice and direction. The court was asked whether the public guardian could legally consent to discontinuance of hydration and nutrition or refuse such treatment on behalf of Const. Durksen and whether a court review was required.

The court's deliberations hinged on 2 questions and the connection between them. First, did the existing legislation allow the public guardian to give proxy consent to discontinue or refuse life-sustaining interventions? Second, did the principle of sanctity of life prejudge what could be determined as being in a person's best interest?

The court held that a courtappointed guardian lacked the power to authorize discontinuance of life support for a person with no advance directive and required the court's approval. The court's decision in this case was to grant the application to discontinue nutrition and hydration and to approve the proposed termination of all measures except purely palliative ones.

In making this determina- 
tion, the court took a pragmatic yet sensitive approach. The starting-point was that court review is essential in the absence of an advance directive: the public guardian cannot act alone. On the substantive issue, the decision indicated the need to address the particular facts involved. With no reported Canadian cases with similar facts, the court considered several factors. These included the English House of Lords decision in Airedale NHS Trust v. Bland (1993), which concerned a 17year-old comatose survivor of the Hillsborough soccer disaster, who had been kept alive on life support for approximately 3 years. As his legal representatives, his parents went to court to get permission to authorize discontinuance of his life support. The decision in that case held that the "existence in a persistent vegetative state is not a benefit to the patient." However, incapacity to benefit does not address the "sanctity of life" issue. Again, the Alberta court adopted the position taken in Bland, namely that the sanctity of life is not an absolute principle. The court took the view that life is sacred, not in the sense of bare existence, but in a personal sense: how that patient construes a meaningful life their life as they see it and how they wish to live. Lack of sufficient quality of life relative to the patient's known values will affect the rightness of a proxy decision about a person. At the same time, the Alberta court also found that a desire to die was not sufficient to warrant a medical intervention solely to bring about death; here, the court cited the Supreme Court of Canada decision in Rodriguez (1993), the case of the BC woman with amyotrophic lateral sclerosis who unsuccessfully sought court approval for physician-assisted suicide.

The Alberta court took into account the extensive consultation of medical and ethical experts and family. It also took into account hearsay evidence from family and friends to identify the patient's values and outlook on life for one in his condition. Const. Durksen had attended the scene of many injuries and fatal accidents and had talked to colleagues about his views. The anecdotal evidence from family and friends indicated that, were he able to do so himself, Const. Durksen would have refused continued life support in his condition. Overall, the court held that the patient's circumstances made it fitting to order the discontinuance of all but palliative care.

Discontinuance of life support for a patient is, and will continue to be, one of the most emotionally difficult situations faced by family, caregivers and health care professionals. It involves intensely personal deliberations about intensely interpersonal matters: what we mean to each other and what we mean to ourselves, and how best to deal with and respond to the monumental change in circumstances. When differences in outlook emerge, those involved risk becoming prey to public lobbying, as seen recently in the Schiavo case. The similarities in circumstances between her case and that of Const. Durksen are striking: both patients were comatose; both were represented by a court-appointed guardian; neither had a living will; and both were in a condition with no realistic prospect of significant improvement or recovery. The essential difference is that Const. Durksen's family found a way to reach consensus in their beliefs about what was best for him and what he would want for himself. If there is a lesson to be learned, it is surely that, in each case, had there been a living will, there would have been no need for a court hearing, and no publicity.

\section{Glenys Godlovitch \\ Barrister and Solicitor \\ Associate Professor of Medical \\ Bioethics \\ Ian Mitchell \\ Director, Office of Medical Bioethics \\ Professor of Pediatrics \\ Christopher James Doig \\ Associate Professor \\ Departments of Critical Care \\ Medicine and Community Health \\ Sciences \\ University of Calgary \\ Calgary, Alta.}

Acknowledgments: We would like to acknowledge the understanding of those members of Const. Durksen's family who have assented to the dissemination of the information surrounding his case in this article. Although this has been a theoretically accessible decision, it has gone more or less unnoticed and has not been included in the usual law reports to date. The hope is that the present disclosure might assist people facing hard decisions in similar situations. We thank senior staff, especially Darrel Koller, at the Office of the Public Guardian (Alberta) for assisting in the preparation of this article. We also thank Robert Bissett, with the law firm of Stringam Denecky, Barristers and Solicitors, who prepared an excellent brief of law and made the application on behalf of the Office of the Public Guardian.

\section{References}

1. Sawatzky v Riverview Health Centre Inc (1998), 167 DLR (4th) 359.

2. In the Matter of Robert Kenneth Durksen, Dependant Adult, Surrogate Court of Alberta, Lethbridge/Macleod (16 Sept 1999), court file DA06-02070 (JCQBA). 